\title{
GUIDED INQUIRY LEARNING MODEL APPLICATION TO TRAIN THE STUDENTS ANALYSIS SKILLS ON FACTORS THAT AFFECT REACTION RATE MATERIALS
}

\author{
Dhevira Aptia Firmanda* and Dian Novita \\ Chemistry Education Study Program, Faculty Mathematics and Natural Science, State University of Surabaya, \\ Surabaya, Indonesia \\ *Email: dheviraaptiafirm@gmail.com
}

\author{
Accepted: January 02, 2022. Approved: January 13, 2022. Published: January 15, 2022
}

\begin{abstract}
The study aims to describe the applicability of learning model implementation, student activities, learning outcomes, students' analytical skills, and student responses with guided inquiry learning models application. The method used is one group pretest-posttest design with 24 students of XI IPA class. Research shows that (1) quality guided inquiry learning percentage during two meetings is $94.44 \%$ and $95.75 \%$, respectively. (2) relevant student activity has an average percentage of $94.64 \%$. (3) student learning outcomes in the factor that affects reaction rate material increases with n-gain scores obtained $83.68 \%$ in the high category. (4) the results of student analytical skills on each component with a high category n-gain score are element analysis was $95.83 \%$, relationship analysis was $58.33 \%$, and analysis of organizational principles was $79.17 \%$. (5) the student response had very good category results with a percentage of $98.61 \%$.
\end{abstract}

Keywords: Guided inquiry learning, Analytical skills, The Reaction rate

\section{INTRODUCTION}

Education is an interaction between students and educators to develop students' knowledge, attitudes, and skills [1]. Education is one of the critical aspects and the primary key to improving the quality and development programs of the nation and state. The education sector is a central position in development to increase human resources, and it is one of the benchmarks in the product's success [2]. However, in 2019 the world was being rocked by the Coronavirus (Covid-19) outbreak which implemented learning of education done online [3]. The implementation of online learning makes it difficult for students to receive and is ineffective due to several obstacles such as connections and electricity [4]. So that at this time, it has been allowed to hold face-toface learning in the green zone while still paying attention to health protocols so that learning becomes effective.

Improving the quality of national education can be taken by the government to include improving the education curriculum, which is currently using the 2013 curriculum. According to the 2013 curriculum, learning patterns are carried out using a scientific approach. That can train thinking skills and scientific work skills, such as the inquiry learning model or problem-based learning (PBL) that educators can apply in schools [5].

Chemistry subjects are included in abstract (sub-microscopic), macroscopic, and symbolic subjects to be referred to as multiple-level representation concepts. So that students widely consider the subject of chemistry as one of the complex subjects, in line with the results of a preresearch conducted in class XI IPA at Senior High School Cendekia Sidoarjo, which stated that as many as $91.67 \%$ of students said that learning chemistry was complex. Some students have difficulty connecting their concepts with the following concept.

One of the main subjects in chemistry lessons is the rate of reaction. The reaction rate is explained by the presence of molecules in the reaction called collision theory to predict the rates of reactions [6]. As many as $75 \%$ of students consider the rate of reaction material to be complex material. $41.67 \%$ of students said that the reaction rate material was complicated because the material contained many concepts.

In the 21st century, analytical skills, part of the critical thinking component, are included in four primary skills [7]. With good analytical skills, students will have good learning outcomes. The analytical abilities have three parts: elemental analysis, relationships, and organizational principles [8].

However, the fact that students lack activities to train analytical skills shows that the results of a preresearch questionnaire support this. The students are given questions to test analytical skills covering three components. The elemental analysis provides an average score of 19.44 , relationship analysis is 25.69 , and analysis of organizational principles is 29.16 , which is still far from the standard value of the minimum completeness criteria.

Students' low analytical skills need to be improved. Active learning models must be introduced to students in learning activities to spur the human brain's performance and enhance student learning outcomes [9]. Guided inquiry learning models can improve students' analytical skills and critical processes by seeking and finding an answer to an existing problem through observation or experimentation [10].

Several studies have proven that the students' analytical skills can be improved with guided inquiry model application, especially in reaction rate material. 
The research shows an inquiry learning model application increases student learning outcomes with a high category n-gain score of about $94.11 \%$. For each analysis component in a row, namely elemental analysis of $64.71 \%$, while the components of the analysis of organizational principles and analysis relationships are $47.06 \%$. Three-component is in the high category [11]. It shows that inquiry learning is effectively used in the reaction rate material to train students' analytical skills. Based on this, the researcher raised a study entitled "Guided Inquiry Learning Models Application to Train the Students' Analysis Skills on Reaction Rate Materials."

\section{RESEARCH METHOD}

Pre-experiment is a type of this study with one group pretest-posttest design. The subject of this research includes 24 students of XI IPA at Senior High School Cendekia Sidoarjo that is on the odd semester of the 2021/2022 school year. One group pretestposttest design can describe the increase in analytical skills with guided inquiry. The subject will do a pretest as a value before learning is applied $\left(\mathrm{O}_{1}\right)$. It is used to determine students' initial ability. Then, a guided inquiry model of sub materials factors that affect the reaction rate $(\mathrm{X})$ is carried out. And to determine students' ability after the learning model was applied to trim, it held a posttest $\left(\mathrm{O}_{2}\right)$.

Data analysis includes data on the applicability of the inquiry learning model, student activities, learning outcomes, students' analysis skills, and student responses to the learning that has been done.

\section{The Applicability of Inquiry Learning Model}

The applicability of the guided inquiry learning was used to describe the learning quality, which three observers assessed following the design of the learning implementation that had been made. The applicability of learning model implementation scores is presented in Table 1 [11]. The interpretation of scores was obtained using the reference percentage as listed in Table 2 [12].

The criteria for success in this learning syntax implementation data are said to be successful if a score of $61 \%$ is obtained or is in good or very good criteria.

Table 1. Criteria Score of Applicability Learning Model

\begin{tabular}{cc}
\hline Score & Criteria \\
\hline 4 & Excellent \\
3 & Well-executed \\
2 & Enough \\
1 & Poor \\
\hline
\end{tabular}

Table 2. Interpretation Score of Applicability Learning Implementation

\begin{tabular}{cc}
\hline Percentage & Category \\
\hline $81-100 \%$ & Very Good \\
$61-80 \%$ & Good \\
$41-60 \%$ & Enough \\
$21-40 \%$ & Poor \\
$0-20 \%$ & Very Poor \\
\hline
\end{tabular}

\section{Student Activities}

Student activities are carried out by observing the activities presented in minutes according to the stages of the guided inquiry model. The data is analyzed by converting into percentages using the formula [13]:

$\%$ Students' Activity $=\frac{\text { the frequency that appear }}{\text { total frequency }} \times 100 \%$

The criteria for success in student activity data are if the percentage of relevant student activities scores $61 \%$ or in good criteria.

\section{Analysis of Pretest-Posttest Learning Outcomes and Analytical Skills}

Students' analytical skills can be known according to the research design. Pretest-posttest is carried out to determine the students' analytical skills using the guided inquiry learning model. The score of students' analytical skills can be measured using the equation:

$$
\text { Grade }=\frac{\text { score that obtained }}{\text { maximum score }} \times 100 \%
$$

The criteria for data analysis ability of students is said to be successful if in one class that is used as the subject, as much as $75 \%$ get a final score that exceeds the minimum competencies criteria.

The improvement of students' analytical skills after applying guided inquiry learning can be used to n-gain score analysis and t-test. The t-test stage of determining research hypotheses and hypotheses is carried out. After implementing the guided inquiry, the research hypothesis is an increase in learning outcomes/ analysis skills seen from students' pretest and posttest scores.

Based on the significance level $(\alpha)$ of 0.05 , the $95 \%$ confidence level, the guidelines for decision making on the data analysis that has been carried out are alternative hypothesis $\left(\mathrm{H}_{\mathrm{a}}\right)$ is accepted, and the $\left(\mathrm{H}_{0}\right)$ is rejected if get $\mathrm{Sig}$. (2-tailed) $<0.05$.

For n-gain data analysis, an equation can be used. The equation to get the gain score is

$$
\mathrm{N} \text {-gain }=\frac{\text { posttest score-pretest score }}{\text { maximum score-pretest score }}
$$

It can be interpreted through the n-gain score criteria in table 4 [11]. 
Table 4. Interpretation Category in Score of N-

Gain

\begin{tabular}{cc}
\multicolumn{2}{c}{ Gain } \\
\hline$\langle\mathrm{g}\rangle$ & Category \\
\hline $\mathrm{g} \geq 0.7$ & High \\
$0.7>\mathrm{g} \geq 0.3$ & Medium \\
$\mathrm{g}<0.3$ & Low \\
\hline Criteria for & increasing students analytical
\end{tabular}

Criteria for increasing students' analytical skills are stated if the n-gain results in the high or medium category, and on the t-test, it is indicated if $\mathrm{H}_{0}$ is accepted.

\section{Student Response Questionnaire}

According to the research design, the student response questionnaire contains questions regarding the response after implementing the guided inquiry learning model. Data analysis of student responses will follow the Guttman scale. The criteria is to answer "yes" get 1 score. And "no" is 0 score [13].

Student response data is then described in the presentation through equation bellow.

$$
\% \text { Student response }=\frac{\text { the number of answer yess }}{\text { total of respondent }} \times 100 \%
$$

Criteria for student response data is when the data gets a percentage $\geq 61 \%$. The criteria are shown in Table 2.

\section{RESULT AND DISCUSSION}

The results and discussion presented in this study include the applicability of the guided inquiry learning model, student activities, learning outcomes, students' analytical skills, and student response questionnaires. This research was conducted at Senior High School Cendekia in class XI IPA with 24 students. The research was carried out in November 2021 with face-to-face learning while still paying attention to health protocols.
The learning instruments used have passed the validation stage. Two validators carried it out to determine the feasibility and validity of the device. Based on the validation phase, it is concluded that the research tools and instruments are suitable for use with revision to carry out data collection activities then.

\section{The Applicability of Inquiry Learning Model}

The guided inquiry emphasizes finding material concepts based on the proposed formulation to be more active in gaining learning knowledge [14]. The implementation of the guided inquiry has a vital role in making students' critical thinking skills improve [15]. This study applied the guided inquiry learning model for two meetings on the sub-material factors affecting the reaction rate. The results of the applicability learning model can be seen in Figure 1 below.

The guided inquiry learning syntax has six phases [16]. The phase-in inquiry learning can be related to practicing analytical skills, such as phase 1 : getting attention and explaining the investigation process; Phase 2: presenting the inquiry problem (phenomenon). Students carry out activities to formulate problems on the phenomena presented, including training components of fundamental analysis skills; Phase 3: ask students to formulate hypotheses to explain the problem. Students carry out hypothetical activities including components of relationship analysis skills; Phase 4: encourage students to collect data to test hypotheses. Students determine the variables and collect data, including the components of elemental analysis; Phase 5: formulating conclusions, including components of the analysis of organizational principles; Phase 6: reflecting on the problem situation and the thought process used to investigate [11].

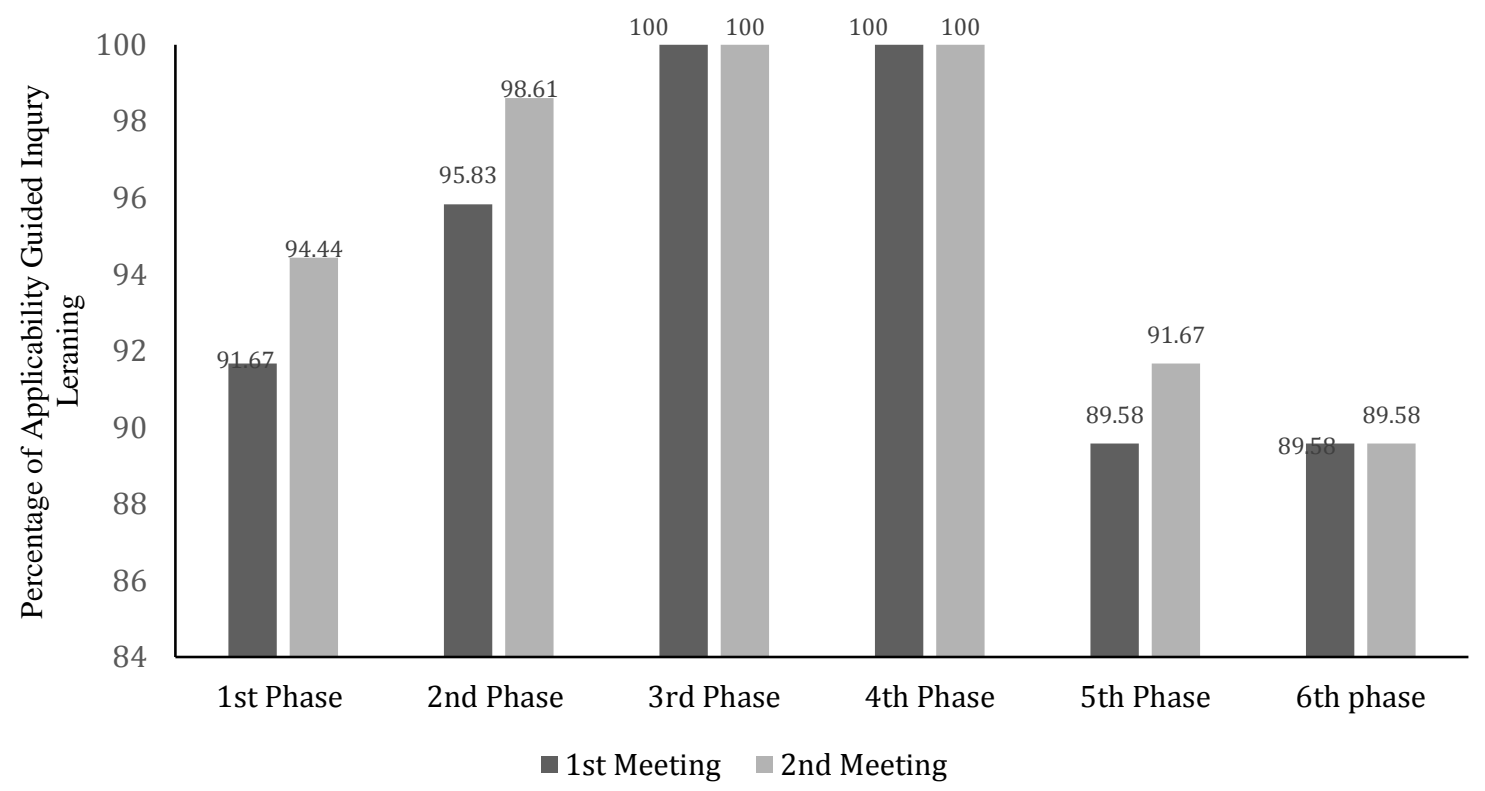

Figure 1. Percentage of the Applicability Learning Model 
Based on Figure 1, the quality of the implementation learning model at each stage has very good criteria. Each average percentage score of the guided inquiry learning phase at each meeting is $94.44 \%, 95.75 \%$. It shows that the teacher can implement the guided inquiry learning model and master the material taught to students to practice analytical skills.

Through this guided inquiry learning model, students will be trained to correctly build their knowledge about the concept of factors that affect reaction rates. The benefits of guided inquiry learning can develop students' attitudes towards science also increase interest and curiosity [17].

\section{Student Activity}

Student activities during the learning process can be a parameter of the quality and success of learning. Relevant and fun learning will make students active in building concepts that can improve students' skills [18]. Observations of student activities are carried out every three minutes to determine whether students practice analyzing and carrying out relevant activities in the learning.

Observing student activities includes several stages to practice analytical skills in the implementation. It is supported by a student worksheet that has been designed to train students' analytical skills. The following is a recapitulation that shows the percentage of student activities in Figure 2.

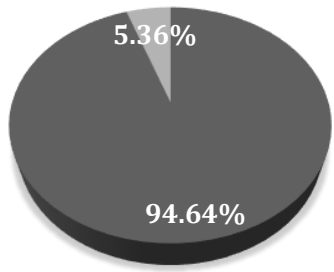

- Relevant Activities Irrelevant Activities

Figure 2. Recapitulation of Students' Activity

Figure 2 is indicated that the activities of students who get the percentage of relevant activities are $94.64 \%$, and irrelevant activities are $5.36 \%$. It shows that students are active and carry out analytical activities seriously, following the research from Kurniasari et al. (2016), which showed that the assessment results of student learning activities had reached the achievement target in the high category or had been met [19].

\section{Learning Outcomes Students}

Posttest scores that reach the minimum completeness criteria (75) of students' cognitive learning outcomes can be seen after implementing a guided inquiry learning model for two meetings. The multiple-choice questions contained 30\% English on the test sheet because bilingual learning was implemented in schools. Students who connect cognitive nerves knowledge will form new knowledge to hone thinking skills [20]. The recapitulation of the differences in students' pretest-posttest results is shown in Figure 3.

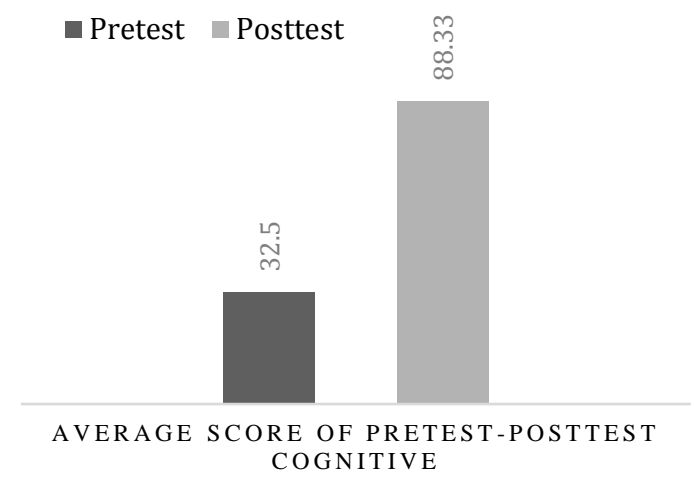

Figure 3. The Differences in Students' Pretest and Posttest Cognitive Results

Through Figure 3, it can be said that pretest and posttest results increase. The calculation of the $n$ gain score is $83.68 \%$, in the high category. It is in line with Waleulu et al.'s (2019) research, which the learning model of guided inquiry can affect student learning outcomes. The students' cognitive learning outcomes have reached the completeness criteria with an average percentage of cognitive learning outcomes (posttest) of $85 \%$ with the application of the guided inquiry model [21].

So this shows that student learning outcomes can be affected by guided inquiry, then strengthened by the presence of student worksheets in each meeting presented by the guided inquiry syntax to encourage students to find a concept and make learning more meaningful. Student worksheets are teaching materials that contain guidelines for developing students' knowledge and skills to be active in learning [22].

\section{Students' Analysis Skills}

An analysis is an activity to examine, count, sort, plot, look for causal factors, groupings, etc., that involves thinking power [23]. The analysis skills have three components: 1) elemental analysis, 2) relationship analysis, and 3) analysis of organizational principles. Students will go through a thinking process to practice analytical skills and are trained not to directly justify everything if it is not proven by logic and common sense [24].

An essay pretest-posttest is used to measure students' analytical skills and include three components of analytical skills. Students will apply the guided inquiry learning model using the media students' worksheet. After carrying out the guided inquiry learning model for two meetings, the next step is to post the posttest. Students' analytical skills were increased using the t-test in the SPSS application and the n-gain score analysis. The average results of the pretest-posttest analysis skills obtained by students are shown in Figure 4. 


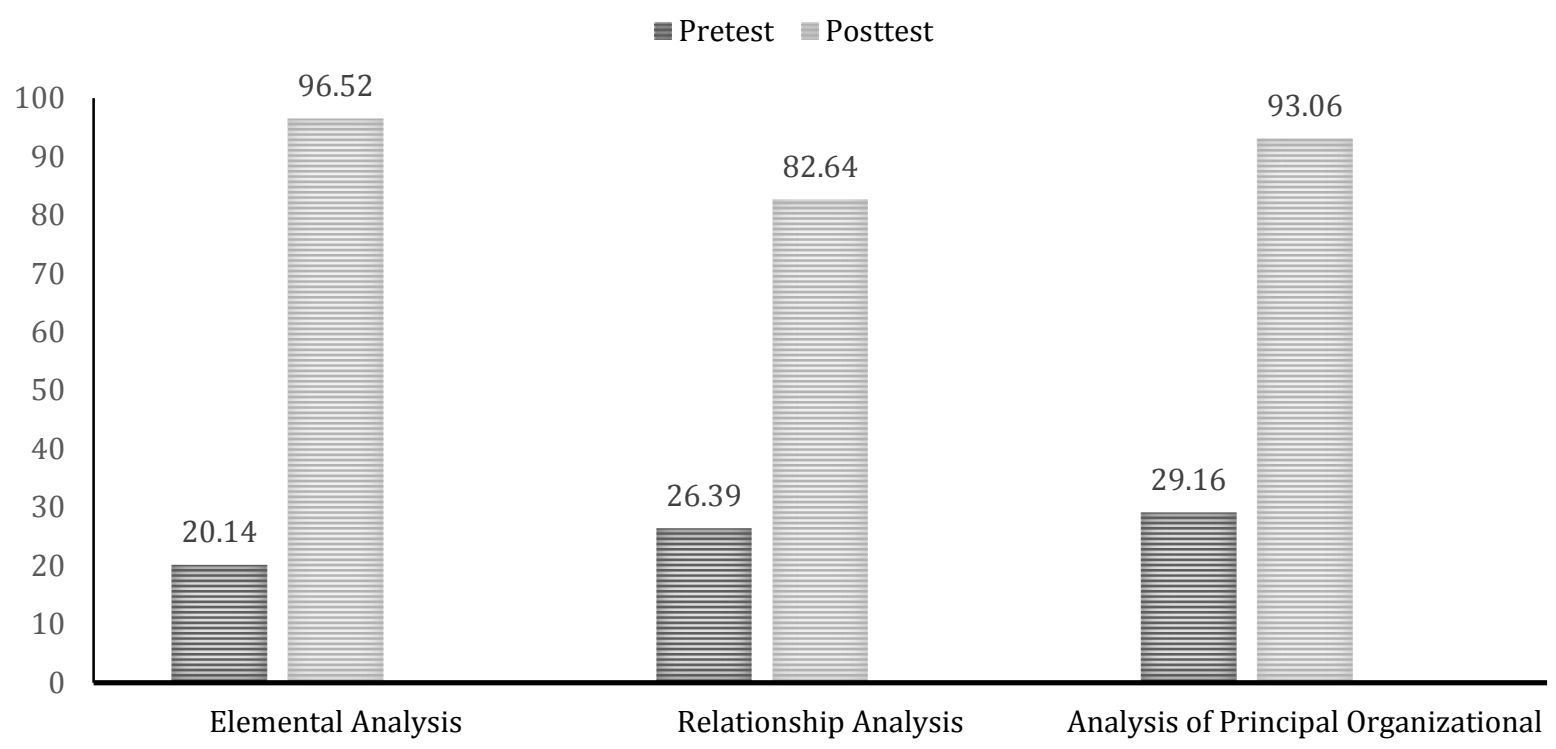

Figure 4. The Result of Pretest - Posttest Analysis Skills in Each Component

Then after the normality test, the pretest and posttest data were then tested with a paired t-test. The result was that the significant value was 0.000 . The value $<0.005$, so $\mathrm{H}_{\mathrm{a}}$ is accepted, which means that pretest-posttest scores have a significant difference. The result of the t-test is in Figure 5.

Table 5. T-Test of Pretest-Posttest

\begin{tabular}{llccc}
\hline & & $\mathrm{t}$ & $\mathrm{df}$ & Sig. (2-tailed) \\
\hline Pair 1 & Pretest - & -27.005 & 23 & 0.000 \\
& Posttest & & & \\
\hline
\end{tabular}

Then the pretest-posttest will provide analysis with the n-gain score. The details of the ngain scores on each component of analytical skills are shown in Figure 6.

$$
\square \text { High } \square \text { Average } \square \text { Low }
$$

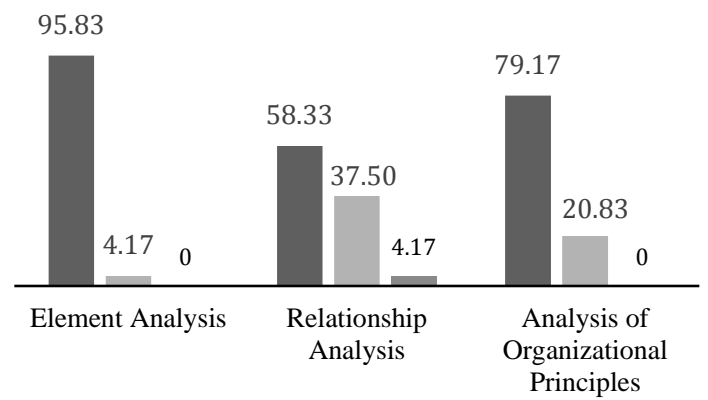

Figure 5. N-Gain Score of Analysis Skills Component

Figure 5. shows that $95.83 \%$ of students have n-gain scores in the high category in the elemental analysis component. Fundamental analysis indicators include several activities such as identifying meaning in a problem, formulating a problem, and determining experimental variables.
Then, the second component of the analysis, namely relationship analysis, consists of $58.33 \%$ in the high category. Indicators of relationship analysis include activities to formulate explanations by linking supporting theories. And the third component of the analysis is the analysis of organizational principles, which gets a high n-gain score of $79.17 \%$ of students. Indicators of the analysis of the organizational tenets are shown through activities to conclude a problem.

Based on the analysis of the n-gain scores on the three components of the analytical skills, relationship analysis has the lowest n-gain criteria scores, with a percentage of $4.17 \%$. The other two components of the analysis, namely elemental analysis, and organizational principle analysis, have $\mathrm{n}$-gain scores in high and medium criteria. The low student relationship analysis skills are because there are still many students who make explanations but do not connect them to the supporting theories that have been obtained. So that students tend to answer at the pretest and posttest with short answers that go straight to the core, without linking the relationship with explanatory theory answer causes as many as $4.17 \%$ of students to have a low n-gain score.

This study aligns with Fauziah et al.'s (2020) research. They obtained the pretest-posttest results of analytical skills with n-gain scores on the elemental analysis component, getting a high criterion of $64.71 \%$. It was followed by the ability to analyze relationships and organizational principles, which have $\mathrm{n}$ gain scores in the high criteria as much as $47.06 \%$. The elemental analysis component has the highest n-gain high scores than the other analysis components. And the components analysis of organizational principles and relationship analysis have the highest percentage of $n$-gain scores in the low category, which is $52.94 \%$ [11]. 


\section{Student Response}

Students can be identified through student responses after the guided inquiry learning model applicated. Through this student questionnaire response, the teacher can reflect on the learning that has been done. Student responses can be recapitulated in Table 5.

Table 5. Recapitulation of Result Students' Response

\begin{tabular}{ccc}
\hline $\begin{array}{c}\text { Number of } \\
\text { Statement }\end{array}$ & Percentage $(\%)$ & Category \\
\hline 1 & 95.8333 & Very Good \\
2 & 100 & Very Good \\
3 & 100 & Very Good \\
4 & 91.6667 & Very Good \\
5 & 100 & Very Good \\
6 & 100 & Very Good \\
7 & 100 & Very Good \\
8 & 100 & Very Good \\
9 & 100 & Very Good \\
Total Average Score & $98.6111 \%$ \\
\hline
\end{tabular}

Based on the results, it was found that overall student responses obtained an average percentage of $98.61 \%$, with a very good category. Through a student response questionnaire, it was found that as many as $95.83 \%$ of students stated that learning with the guided inquiry model was fun, easy to follow, and could improve understanding of the material factors that affect reaction rates. So that this inquiry learning model proves to be of positive value to be applied because students need to be more active in each phase. The guided inquiry has characteristics that emphasize learning by providing students with opportunities to explore and discover concepts of knowledge [21].

The study is in line with Patimapat et al. (2019) research, which obtained student responses get very good criteria with a percentage of $86.03 \%$. And also, students feel happy with the application of guided inquiry learning [25]. It also can make students more active and involved in science learning to build a better understanding [26].

\section{CONCLUSION}

The guided inquiry learning application can practice analytical skills. The result of applicability of learning model, students activities, and student response have very good criteria. And based on the research, guided inquiry learning has increased the learning outcomes and students' analysis skills. For the following research, it suggested adding features about relationship analysis in the students' worksheet.

\section{REFERENCES}

[1] Dewita, R., \& Ahda, Y. (2019). Improvement of Critical Thinking Skills of Students of Class X MIA MAN 3 Kota Padang Panjang Using Guided Inquiry Learning Model. International Journal of Progressive Sciences and Technologies (IJPSAT), 17(1), 142-147.
[2] Yuliani. (2016). Pendidikan Di Indonesia Dalam Human Development Index (HDI). Jurnal Rontal Keilmuan PPKn, $\mathrm{I}(\mathrm{V}), 48-57$.

[3] Nissa, S., \& Haryanto, A. (2020). Implementasi Pembelajaran Tatap Muka Di Masa Pandemi Covid-19. Jurnal IKA: Ikatan Alumni PGSD Unars, 8(2), 402-409.

[4] Hatmo, S. H. (2021). Dampak Pandemi Covid-19 Terhadap Efektivitas Pembelajaran Jarak Jauh Secara Daring. Scholaria: Jurnal Pendidikan dan Kebudayaan, 11(2), 115-122.

[5] Mauliza, \& Sari, R. (2018). Analisis Kebutuhan Perencanaan Pembelajaran Berbasis Kurikulum 2013 Dalam Pembelajaran Kimia Di SMA. Chemica: Jurnal Pendidikan Kimia dan Ilmu Kimia, 1(1), 26-34.

[6] Sodiqovna, O., \& Qizi, I. (2020). The Rate of a Chemical Reaction And Factors Affecting It. EPRA International Journal of Research and Development (IJRD), 5(8), 261-263.

[7] Redhana, I. (2019). Mengembangkan keterampilan abad ke-21 dalam pembelajaran kimia. Jurnal Inovasi Pendidikan Kimia, 1(13), 2239-2253.

[8] Niana, R., Sarwanto, \& Ekawati, E. (2016). The Application of Guided Inquiry Model On Physic Learning To Improve Scientific Attitude And Students' Analysis Ability. Proceeding The 2nd International Conference On Teacher Training and Education Sebelas Maret University, 2(1), 605-615.

[9] Novita, S., Santosa, S., \& Rinanto, Y. (2016). The Comparison of Student Analitycal Thinking Between the Implementation of Cooperative Learning and Guided Discovery Learning Model. Proceeding Biology Education Conference, 13(1), 359-367.

[10] Hamdayana, J. (2016). Metodologi Pengajaran. Jakarta: Bumi Aksara.

[11]Fauziah, F., \& Novita, D. (2021). Training The Analysis Skills of Student Through the Application of Guided Inquiry Learning Models Onreaction Rate Materials. JPPS (Jurnal Penelitian Pendidikan Sains), 10(2), 1932-1948.

[12] Riduwan. (2016). Skala Pengukuran Variabelvariabel Penelitian. Bandung: Alfabeta.

[13] Arifin, Z. (2012). Penelitian Pendidikan. Bandung: PT. Remaja Rosda Karya.

[14] Aris, S. (2014). Model Pembelajaran Inovatif dalam Kurikulum 2013. Yogyakarta: Ar-Ruzz Media.

[15] Firdausichuuriyah, C., \& Nasrudin, H. (2017). Keterlaksanaan Penerapan Model Pembelajaran Inkuiri Terbimbing Untuk Meningkatkan Keterampilan Berpikir Kritis Siswamateri Larutan Elektrolit dan Non Elektrolitkelas X SMAN 4 Sidoarjo. UNESA Journal of Chemical Education, 6(2), 184-189.

[16] Arends, R. (2012). Learning to Teach Tenth Edition. New York: McGrawHill Education. 
[17] Imanah, I., Saputro, S., \& Ashadi. (2017). Pengembangan Modul Kimia Berbasis Inkuiri Terbimbing Pada Pokok Bahasan Termokimia Untuk Sma/Ma Kelas XI. Jurnal Inkuiri, 6(1), 161-174.

[18] Dijaya, A., Pitasari, R., \& Kurniasih, S. (2018). Penerapan Model Pembelajaran Inkuiri Terbimbing untuk Meningkatkan Keterampilan Proses Sains Siswa pada Konseplarutan Elektrolit Dan Nonelektrolit. JTK: Jurnal Tadris Kimiya, 3(2), 190-198.

[19] Kurniasari, A., E.S., W., \& Utomo, S. (2016). Penerapan Model Pembelajaran Inkuiri Terbimbing untuk Meningkatkan Aktivitas dan Prestasi belajar Siswa pada Materi Kelarutan dan Hasil Kali Kelarutan Kelas XI IPA 2 SMA Negeri 1 Karanganyar Tahun Pelajaran 2015/2016. JPK Jurnal Pendidikan Kimia, 5(4), 98-106.

[20]Bunga, D. A. (2018). Pengaruh Model pembelajaran Inkuiri Terbimbing terhadap kemampuan Berpikir Kritisdan hasil belajar peserta didik kelasX MIA SMA Negeri 2 Barru. Jurnal Sains dan Pendidikan Fisika, 1.

[21] Waleulu, A., Muharram, M., \& Sugiarti, S. (2019). Pengaruh Model Pembelajaran Inkuiri Terbimbing terhadap Kemampuan Berpikir Kritis dan Hasil Belajar Peserta Didik. Chemistry Education Review, 3(1), 8-16.

[22] Hariadi, N., Rasmiwetti, \& Haryatu, S. (2002). Pengembangan Lembar Kegiatan Peserta Didik Berbentuk Majalah Berbasis Berpikir Kritis pada Materi Laju Reaksi Kelas XI Sekolah Menengah Atas. J. Pijar MIPA, 15(5), 434-437.

[23] Handayani, S., \& Dewanti, M. (2020). Peningkatan Kemampuan Analisis Melalui Strategi PQ4R (Preview, Question, Read,Recite, Reflect, Review) Pada Pembelajaran IPA Sekolah Dasar. Jurnal Publikasi Pendidikan, 10(3), 202210

[24] Sartika, S., Efendi, N., \& Rochmah, L. (2020). Peningkatan Keterampilan Berpikir Analisis Calon Guru IPA Melalui Model 4A (Analisis Fenomena, Analisis Informasi, Analisis Data, Analisis Temuan). Jurnal Pendidikan Sains (JPS), 8(2), 165-170.

[25] Patimapat, M., Duda, H., \& Supiandi, M. (2019). Efektivitas Model Pembelajaran Inkuiri Terbimbing Melaluimetode Demonstrasi Terhadap Hasil Belajar Psikomotorik Siswa. Jurnal Pendidikan Biologi (JPBIO), 4(1), 09-20.

[26] Wati, S., Idrus, A. A., \& Syukur, A. (2021). Analysis of Student Scientific Literacy: Study on Learning Using Ethnoscience Integrated Science Teaching Materials Based on Guided Inquiry. $J$. Pijar MIPA, 16(5), 625-630. 